\title{
THE FLOWERING HABIT AND NATURAL CROSSING IN THE EGG-PLANT
}

\author{
YÔITI KAKIZAKI \\ Saitama Agriculerural Experiment Station, Urawa, Saitama
}

In regard to the frequency of natural crossing in the egs-plant, Solanum Melongena, L., no exact experiment has ever been made so far as. the author" is aware. Some Japanese seedsmen are of the opinion that the natural crossing in this plant is a matter of no importance, and lence that, from the seed raising point of view, the plant can practically be treated as an autogamous one. Others, on the contrary, hold that if careful selection is not practised constantly, the variety will degenerate season after season on account of the natural crossing. Hoping to throw some light on the subject, the author made with this plant some observations on the flowering habit and also an experiment for ascertaining the percentage of the natural crossing.

\section{The Flowering Habit and the Mechanism of Flowers}

The egg-plant shows a peculiar habit in flower setting (Fig. I), i.e., the flower is not set in the leaf axil as in the ordinary plants but on the stem itself, and sometimes on lower and sometimes on upper parts of the internode. The first flower appears as a rule on a definite internode of the main stem, though this first flowering internode may vary from the seventh to the thirteenth according to the difference of varieties or strains. After the appearance of the first flower, the node just below the flower shoots the first branch which exhibits almost the same vigor as the upper part of the main stem, and thus a type of pseudo-dichotomy is formed. Two flowers, then, are set almost at the same time, one on the next internode but one to the first flowering one, and the other on the third internode of the first branch; these two flowers are named in this paper "the second flowers." The fruits born from the second flowers are called by some Japanese seedsmen "tenbin-no-mi" or "balanced fruits," because these fruits grow almost in balance. The node just below each of the second flowers usually shoots a branch. These branches bear flowers on their third internodes, and almost at the same time the main stem and the first branch also bear flowers on the next internodes but one to those with the second flowers; the group of these flowers are named "the third flowers." In the same way, 


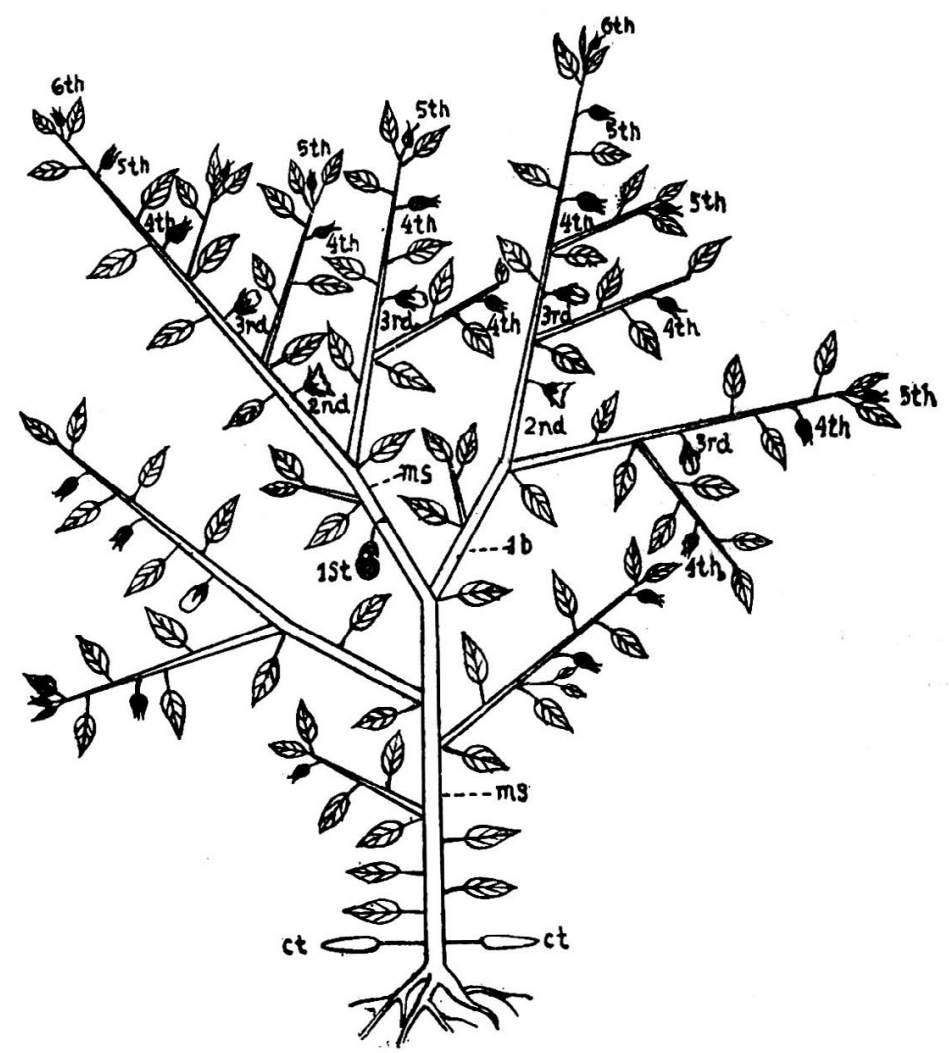

FIG. 1. A dianram showing the flowering habit of the egg-plant; $c t$, cotyledon; ms, main stem; 1b, first branch; $1 s t, 2 n d$, $3 r d$, etc. designate the order of flower setting. The two fruits born from the flower designate 1 by " 2 d" " are "cmbin-no-mi" or " balanced fruits."

"the fourth flowers," "the fifth flowers," and the like are set in their turns if the condition is favorable. Meanwhile, the nodes lower than the first branching node of the main stem shoot also some branches, of which one or two upper ones display a flowering habit similar to the one seen in the case of the first branch. One peduncle bears sometimes two or three flowers, but usually only one of them is potent.

The flower is directed obliquely downwards, and remains open for two or three days without closing even at night. The number of anthers of a single flower varies, with different varieties, from six to twenty or more. It shows usually a deviation of two or three anthers with different plants in the same variety and even with different flowers of one and the same plant. The anthers of a flower converge in such a way that they form a cone which surrounds the style; the latter projects out of the cone of anthers 
bending slightly downwards. The construction of the flower being such, the stigma is first touclied by insect visitors. Sometimes a peculiar flower is born, in which the style is short and the stigma does not come out of the cone of anthers. The flower of such type is barren generally and does not bear fruits even when artificially pollinated. The stigma matures as soon as the flower opens, and receives pollen for a period of two or three days in general. The period for which the stigma is potent is shortened or elongated according to the rise or fall of temptrature at the season, and also somewhat elongated when the stigma is not pollinated. The stigma in a fiesh state is light yellow in color, while it becomes dusky on withering. The anthers dehisce at the terminal pores a short time afer the flower has opened; insects, wind or anything touching or shaking them let much pollen fall. The pollen is, however, so dispersed by the agency of the wind that the stigma can not receive sufficient amount of pollen; and if the flower is wrapped with paraffined paper before blooming, the better part of pollen is preserved in anthers and remains alive until the stigma loses almost its proper function.

\section{The Fixperiment on Natural Crossing}

Varieties of the egg-plant are grouped into two main types, the black and the white. The black type shows black or dark purple coloration on the skin of unripe fruits as well as on the vegetative part, the white exhibiting no such coloration at all. This difference of coloration is very distinctive in the lyypocotyle of the seedling. When a cross is made between these two types, the resulting $F_{1}$ hybrid is black, and the $F_{2}$ segregates at the ratio of 3 blacks: I white; hence these two characters can be said to be dependent on a single factor difference, black being dominant. Accordingly, if the white is cross-fertilized accidentally by the black, the hybrid produced can be readily detected in the seedling stage by its black hypocotyle.

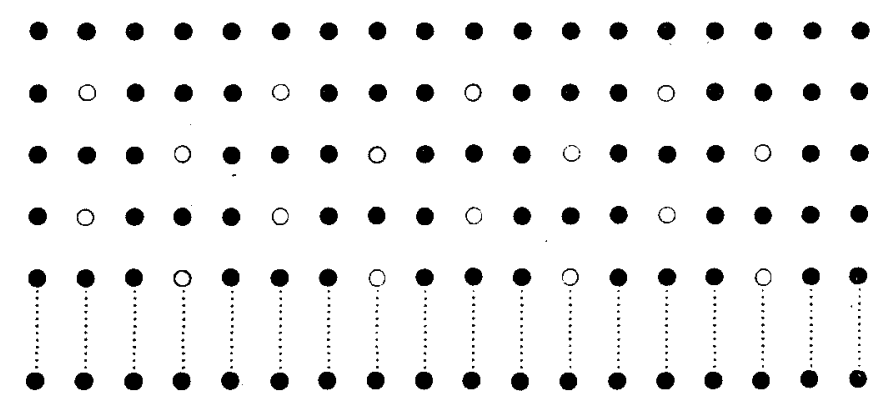

Fig. 2. A diagram showing the scheme of planting used for the purpose of lesting the natural crossing in the egg-plant: $O$, the plant of the white variety; and 9 , that of the black variety. 
In 1922, a white variety "Sironasu" and a black variety "Sinkuro" were mix-planted in a field in such a scheme as shown in Fig. 2, the rowand hill-distances being 3 and 2 feet respectively. In this scheme of: planting, most of the crossings which occur in the plants of the white aregenerally of fertilization by those of the black, though only a few are by theother plants of the white.

The plants of the black variety began to bloom several days earlierthan those of the white variety. This is rather convenient for the purpose of experiment, because, if adversely the white would bloom earlier than the: black, early-blooming flowers of the former would as a matter of coursenever come in contact with those of the latter. Fruits born by the white were left without interference until they ripened, while those by the black were harvested one after another when each fruit reached the weight of ahout three ounces.

There were produced 63 seed-fruits by 25 plants of the white variety. The seeds obtained from each of the fruits were separately sown in a frame in the spring of the following year (1923), and the seedlings raised were examined.

table i. Percfintages of Natural Crossing in Separattr frutts

\begin{tabular}{|c|c|c|c|c|}
\hline Plant No. & $\begin{array}{l}\text { Order of Flower } \\
\text { Setting }\end{array}$ & $\begin{array}{c}\text { Total of Seedlings } \\
\text { Produced }\end{array}$ & $\begin{array}{l}\text { Number of } \\
\text { Hybrie's }\end{array}$ & $\begin{array}{l}\text { I'ercentage of } \\
\text { Hybrids }\end{array}$ \\
\hline 7 & Ist & 595 & I & 0.2 \\
\hline I 7 & $4^{\text {th }}$ & 580 & 6 & 1.0 \\
\hline 6 & ist & 729 & 9 & 1.2 \\
\hline 7 & $4^{\text {th }}$ & 819 & II & $1 \cdot \hat{3}$ \\
\hline $2 \mathrm{I}$ & $6 \mathrm{th}$ & $7 \mathrm{II}$ & 10 & I. 4 \\
\hline 6 & $2 \mathrm{ndl}$ & $I: 43 \mathrm{I}$ & 23 & 1.6 \\
\hline 6 & $3^{r d}$ & 942 & 16 & I 7 \\
\hline 9 & Ist & 652 & I I & I. 7 \\
\hline$I_{3}$ & ist & $1,4.38$ & 27 & 1.7 \\
\hline$=I$ & Ist & $3^{89}$ & 7 & 1.8 \\
\hline $\mathbf{I}$ & $2 n d$ & $5 ; 6$ & 12 & 2.1 \\
\hline 9 & $3 \mathrm{rd}$ & $1: 446$ & $3^{\circ}$ & 2.1 \\
\hline 25 & $5^{\text {th }}$ & 356 & 9 & 2.5 \\
\hline 2 & I st & 3,598 & 98 & 2.7 \\
\hline 20 & $3 \mathrm{rdl}$ & 645 & I9 & 2.9 \\
\hline 21 & 2nd & 955 & 29 & 3.0 \\
\hline 5 & Ist & $9 \times 1$ & 28 & $3 \cdot 1$ \\
\hline I 3 & $3^{r d}$ & 393 & $I_{3}$ & $3 \cdot 3$ \\
\hline 4 & Ist & 2,702 & 95 & 3.5 \\
\hline 8 & 2nd & 717 & 29 & 4.0 \\
\hline 9 & Ist & 1,265 & $5^{2}$ & 4. I \\
\hline $1_{3}$ & $2 n d$ & $55^{6}$ & 23 & 4.1 \\
\hline
\end{tabular}


table I. Percentages of Natural Crossing in Srparate Fruits (continzted)

\begin{tabular}{|c|c|c|c|c|}
\hline Piant No. & $\begin{array}{l}\text { Order of Flower } \\
\text { Setting }\end{array}$ & $\begin{array}{l}\text { Total of Seedlings } \\
\text { Produced }\end{array}$ & $\begin{array}{l}\text { Nuniber of } \\
\text { Hybrids }\end{array}$ & $\begin{array}{c}\text { Percentage of } \\
\text { Hybrids }\end{array}$ \\
\hline 23 & $3^{r d}$ & $\mathrm{I}, 20 \mathrm{I}$ & $5^{\circ}$ & 4. I \\
\hline 16 & Ist & 890 & 37 & 4.2 \\
\hline 12 & $5^{\text {th }}$ & $\mathrm{x}, \mathrm{x} 25$ & 49 & $4 \cdot 3$ \\
\hline 17 & Ist & $7^{\circ 0}$ & $3^{\circ}$ & $4 \cdot 3$ \\
\hline 24 & 2nd & 937 & 40 & $4 \cdot 3$ \\
\hline I I & Ist & 710 & 35 & $4 \cdot 5$ \\
\hline 23 & $3^{\mathrm{rdl}}$ & $I, 224$ & 61 & 5.0 \\
\hline 8 & Ist & $2 I I$ & II & 5.2 \\
\hline 12 & $5^{\text {th }}$ & $5^{812}$ & $3 \mathbf{I}$ & 5.3 \\
\hline 2 & $5^{\text {th }}$ & 402 & 22 & $5 \cdot 5$ \\
\hline Io & Ist & 926 & 51 & 5.5 \\
\hline 23 & $3^{\mathrm{rd}}$ & 976 & 57 & 5.8 \\
\hline 7 & $4^{\text {th }}$ & 17 & I & 5.9 \\
\hline 12 & 6 th & 988 & 61 & 6.2 \\
\hline $\mathbf{I}$ & I st & $\mathbf{I}, 8 \mathbf{I}_{4}$ & I I 4 & 6.3 \\
\hline 23 & $4^{\text {th }}$ & $1,59 \mathrm{~S}$ & IOI & 6.3 \\
\hline 23 & $4^{\text {th }}$ & 867 & 59 & 6.8 \\
\hline 24 & 2nd & $55^{8}$ & 39 & 7.0 \\
\hline 18 & $3 \mathrm{rd}$ & 735 & 52 & 7.1 \\
\hline 4 & and & 2,215 & $16 x$ & $7 \cdot 3$ \\
\hline IO & 2nd & 935 & 70 & 7.5 \\
\hline 18 & 2nd & 1,095 & $8_{3}$ & $7 \cdot 5$ \\
\hline 7 & $3^{\mathrm{rd}}$ & $9^{88}$ & 78 & 7.9 \\
\hline 5 & $2 n \pi$ & 61 & 5 & 8.2 \\
\hline 22 & Is st & 443 & 37 & 8.4 \\
\hline 22 & $3^{\mathrm{rd}}$ & 673 & 59 & $8.8:$ \\
\hline 21 & $5^{\text {th }}$ & 706 & $6_{3}$ & S.9. \\
\hline 20 & $4^{\text {th }}$ & 259 & 24 & $9 \cdot 3$ \\
\hline 17 & and & $S_{9 I}$ & 86 & 9.8 \\
\hline 6 & 2nd & 906 & $9^{8}$ & 10.6 \\
\hline 12 & $6 t h$ & 918 & 108 & I I.S \\
\hline 12 & $6 \mathrm{hh}$ & 656 & 79 & 12.0 \\
\hline 14 & Ist & $3,79=$ & 467 & $12 \cdot 3$ \\
\hline 15 & Ist & 887 & I 10 & $\mathrm{I} 2.4$ \\
\hline 19 & Ist & $5^{5} 5$ & So & 13.7 \\
\hline 13 & $3^{r d}$ & 323 & $4 \delta$ & 14.9 \\
\hline 24 & Ist & $3^{66}$ & 57 & 15.6 \\
\hline 14 & 2nd & $3^{\circ}$ & $7^{6}$ & 25.2 \\
\hline I & $2 \mathrm{nd}$ & 75 & 22 & $29 \cdot 3$ \\
\hline 12 & Ist & $\mathrm{g}^{\mathrm{So}}$ & 315 & 32.1 \\
\hline 20 & Ist & 389 & 182 & 46.5 \\
\hline \multicolumn{2}{|l|}{ Total } & 57,291 & 3,762 & 6.57 \\
\hline
\end{tabular}


The result obtained is shown in the table $\mathrm{r}$. Among the total number of 57,29I seedlings, there were observed 3,762 black-colored ones. This shows a natural crossing of 6.57 per cent.

table il. Frequencies of Percentagts of Naturai. Crossing

\begin{tabular}{c|c}
\hline \hline Percentage of Hybrids & Number of Fruits \\
\hline $0.1-5.0$ & 29 \\
$5.1-10.0$ & 22 \\
$10.1-15.0$ & 7 \\
$15.1-20.0$ & 1 \\
$20.1-25.0$ & 0 \\
$25.1-30.0$ & 2 \\
$30.1-35.0$ & 1 \\
$35.1-40.0$ & 0 \\
$40.1-45.0$ & 0 \\
$45.1-50.0$ & 1 \\
\hline Total & 63 \\
\hline
\end{tabular}

The amount of natural crossing in separate flowers, as seen in the table II, range from 0.2 to 46.8 per cent, no flower having in fact performed complete self-fertilization. The crossing less than io per cent was quite general, and yet that of much higher percentages was not of so rare cases as we might expect.

table iII. Percentages of Naturat Crossing grouped according to DifFerint ORuers of Flower Seting.

\begin{tabular}{|c|c|c|c|c|}
\hline $\begin{array}{l}\text { Order of Flower } \\
\text { Selting }\end{array}$ & $\begin{array}{l}\text { Number of } \\
\text { Fruits }\end{array}$ & $\begin{array}{l}\text { Total Number of } \\
\text { Seedlings }\end{array}$ & $\begin{array}{l}\text { Number of } \\
\text { Hybrids }\end{array}$ & $\begin{array}{l}\text { Percentage of } \\
\text { Hybrids }\end{array}$ \\
\hline Ist & $2 I$ & 23,707 & 1,799 & 7.59 \\
\hline and & 16 & 13,454 & 846 & 6.29 \\
\hline $3 \mathrm{rd}$ & I I & 9,546 & 483 & 5.06 \\
\hline $4^{\text {th }}$ & 6 & 4,140 & 202 & 4.88 \\
\hline $5^{\text {th }}$ & 5 & $3,17 \mathrm{I}$ & I 74 & $5 \cdot 49$ \\
\hline 6th & 4 & 3,237 & $25^{8}$ & 7.88 \\
\hline Total & 63 & 57,291 & 3,762 & 6.57 \\
\hline
\end{tabular}

Here we must make some consideration about the relation between the order of flower setting and the tendency of natural crossing, because some Japanese seedsmen believe that the " balanced fruits," i.e., the fruits from the second flowers, give the seed which promises the least running out. An answer to the question may be given by the table III, which shows that the 
order of flower setting is of little significance in regard to the frequency of natural crossing.

\section{Fruitfulness of the Emasculated Flowers left to Natural Pollination}

The foregoing result shows that the frequency of natural crossing in the egg-plant is not so insignificant as usually believed. From this fact, one may expect the possibility of emasculated flowers producing fruits by natural cross-pollination. To ascertain this possibility, an experiment was made in I 923 on a small scale.

The white and the black varieties were planted in alternate row, the row- and hill-distances being 3 and 2 feet respectively. In the flowering season, some flowers of the white were emasculated before blooming; and some of the emasculated flowers were left to natural cross-pollination, the others being pollinated artificially when bloomed with pollen from the black. All the flowers of the white except the emasculated ones were taken off before blooming.

TABLE IV. Fruitfulness of Emasculated Flowers

\begin{tabular}{l|r|r|r}
\hline \multirow{2}{*}{ Treatment after Emasculation } & \multicolumn{3}{|c}{ Number of Flowers } \\
\cline { 2 - 4 } & Treated & Bearing Fruits & Bearing No Fruit \\
\hline Pollinated artificially & 14 & 13 & 1 \\
I.eft to natural pollination & 23 & $\mathbf{1}$ & $\mathbf{2 2}$ \\
\hline
\end{tabular}

The result obtained is shown in the table IV. From 23 flowers left to natural cross-pollination only I fruit was obtained, while by 14 flowers pollinated artificially I 3 fruits were produced. This unfruitfulness of the emasculated flowers left to natural pollination is perhaps due to insufficient amount of pollen supplied to the stigma.

It may be mentioned here that the plants which were cultivated in a net house of fine meshes so as to be protected from insects bore much less number of fruits than in case of natural pollination, unless their flowers were pollinated artificially. This is also perhaps due to the insufficiency of pollen supply, as in such a case the wind, as noted before, disperses most of pollen.

\section{CONCLUSION}

It should be affirmed, so far as the present study is concerned, that the natural crossing in the egg-plant takes place quite frequently. The fact seems to be due mainly to the following reasons: (I) the flower is so constructed that the insect visitor may touch the stigma with her body carrying 
the pollen from other flowers before acting as a go-between within the flower, (2) the pollen supply to the stigma by the agency of the wind is apt to be insufficient for bearing fruit, and so the flowers often fail to give fruits without the agency of insects. Consequently, the genetical research with the egg-plant needs artificial control of pollination. In the seed-raising of the plant, too, the artificial self-pollination may deserve practical application, because the practice is not only comparatively easy, but also much seed can be obtained from a single fruit.

摘 要

茄子の開花習性こ自然艾配

栝 崎 洋一

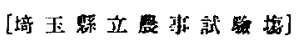

茄子に於ける自然交配の多少に關しては、未だ正確なる實驗を行へるものなき ちの・如く、從つて、そが探種上の應朋に就きても、人に低りて意見を買にす。依

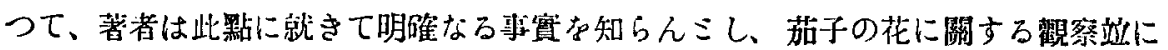
自然交配率調查の實驗を行へり。

茄子は、一般植物の如く花を葉腋に着生するここなく、節間に着生する奇習を有 す。(本交第一㖥參照。ct は子集、ms は主幹、1b は第一枝、Ist, 2nd，3rd 等は花の着次を示す) 而して、第一花の着纵す万節間は品種に低りて略ほ一定し、第七次乃至第十三次節 間こす。第一花出現後、其值下の節より第一枝を纵じ、其第一枝は主幹の上上部こ 㱠んミ゙同程度の發育をなし、以て议狀ジら一種の Pseudo-dichotomy 出現する に至る。Pがて、第一枝第三次節間、及び主幹第一花着生節間の次の次の節間に、殆 えぶ同時に花を看生す。之等雨花を假に第二次こ呼ぶ゙へし。之等二個の第二炏花よ り生ず顆は、殆んぶ均衡的に發育するが故に、浴に「天科の顆」ミ稱せらる。炏 に、第二次花直下の節より更に枝を组からる常こし、“其枝の第三次節間、及仗主幹 ミ第一枝ミの第二次花着生简間の次の次の節間に、殆んこ同時に花を着生す。之等 の花を第三次花ミ目ぶへし。斯くして、適况にある洔は順次第四次花、第五次花等 形成す。此間、主幹第一枝發生䉍以下の數節よりも枝を生じ、內上位のもの一二 枝は上述第一枝に於けるが如き着花をなす。一の花梗に二花乃至三花を着生するこ ミむれごも、結顆するものは內一花なるを峉ミら。

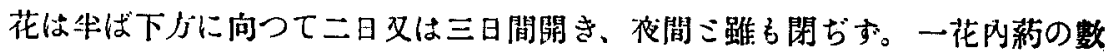


は品種に依りて六個乃至二十個內外の範圍にあり、一品種队におりても粎の相違。

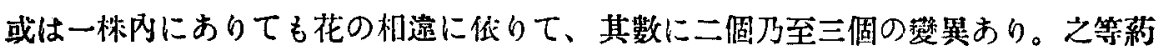
は、抽山せる一個の柱頭を山心にして周圍に圓錐狀㣙なして集合す。從つて、花を

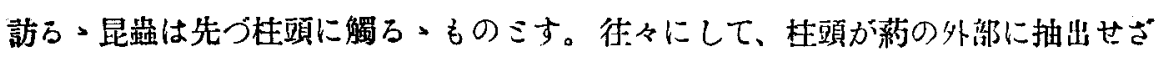

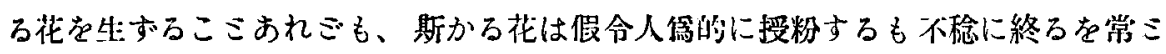
す。杜頭は、開花直後より二三日間花粉を受くる状態にあれごも、其期間は氣温の 如何に依りて伸縮せられ、また授粉せられざる洔は多少延長せらる。此期聞存過ぐ

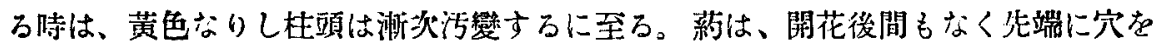

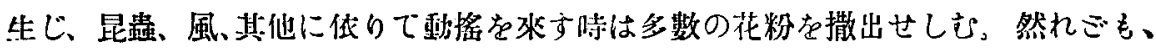
風に依万時は、大部分飛散して柱頍に允分の花粉を興へざるここおり。若し、開花

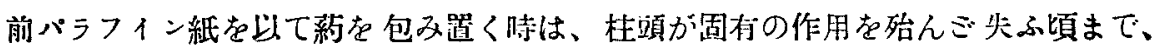
花粉の大部分は葯內に生存す。

沃に，自然交配率調查の實驗に於ては、大正ナ一年、本交第二圖に示すが如く

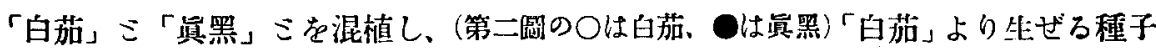

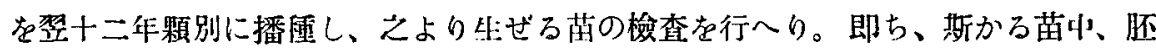
軸綠色ならものは自花授精種子より生ぜるものにして、其紫黑色なるものは「鲳黑」 この恋配種子より生ぜるものなり。其結果合計 25 棑 63 顆より 57,291 本の苗を

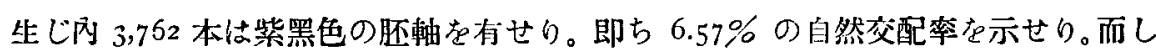
て、之を顆別に見る洔は、完全に自家授精せるもの一花もなく、自然交配率 $0.2 \%$

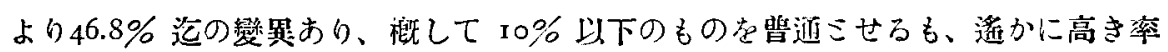
赫せるものも亦珍らしからざりき。佮に、花の着次の差異に低りて、自然交配率 に特殊の差哄むるな認めざりき。

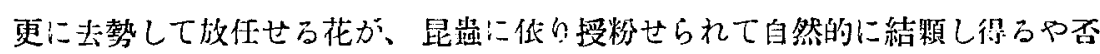

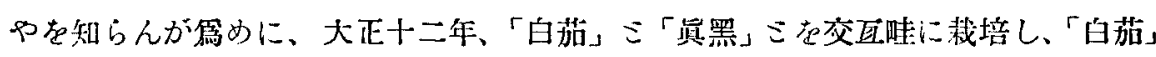
の花 37 花在去勢し(去勢せる外の「白茄」の花は全部摘去す)、队 $\mathrm{x} 4$ 花は「冝品」 の花粉在以て人䉆的に授粉し、殘り23 花は授粉するここなく自然に放置せり。其 結果、前者は 13 顆結び不結顆のものエ花あるに過ぎざりしる、後者中 22 花は

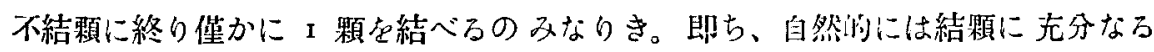
數の花粉粒犯受け奞きもの・如し。

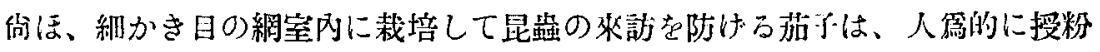
するに非ざれば、概して結顆率低し。え办授粉の不老分なるに基くものなるが如し。

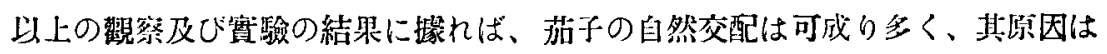

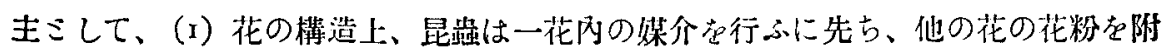


着せる體を凶て先つ柱頭に觸る・ここ、（2）風に依る授粉は結顆するに不充分にし て、昆䩶のわ籍らざれば往々にして不結顆に終らここの二點におろもの・如し。

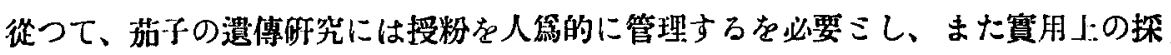
種に當りても、人第的自家授粉は比校的簡易なるのみならす、一花より多數の種子 を得べきが故に゙を行ふを得策こす。 